\title{
Characterisation of the Manufacturing Sectors of High and Medium-High Technology Compared with Other Industrial Sectors
}

\author{
Marco Antonio Villamizar ${ }^{1}$, Angel Cobo ${ }^{2 *}$, Rocío Rocha ${ }^{2}$
}

\begin{abstract}
This study aims to identify the main characteristics of the activities concentrating on R\&D and innovation in the industrial sector of high and medium-high technology, and also the main differences with regard to non technological sectors. In order to do so we use data on 1540 manufacturing companies in Spain in two subgroups according to the National Classification of Economic Activities (CNAE). The data correspond to the values of 44 variables organised into 5 blocks of activity that have to do with R\&D and innovation. The study includes an exploratorydescriptive analysis with the aim of providing information, and evidence of the outstanding characteristics of sectors with more technological components compared with other industrial manufacturing sectors. Although the study refers to Spanish companies, a large proportion of the results are easily transferrable to similar socioeconomic environments.
\end{abstract}

Keywords: High Technology; Medium-High Technology; innovation, R\&D.

Submitted: Jun $13^{\text {th }} 2016 /$ Approved: February $9^{\text {th }} 2017$

\section{Introduction}

Sectors with a high added value, such as the production of high technology that requires a more demanding preparation, have not experienced the desired drive and are still in a minority in Spain (as far as the number of companies, the generation of employment, and added value are concerned). The result of all this is a lower competitiveness than other neighbouring countries (Instituto de Estudios Fiscales, IEF, 2014).

With the aim of analysing the impact of technology on industrial performance, it is important to be capable of identifying those industries and products that are more technology-intensive by means of special classifications (Hatzichronoglou, 1997). In Spain in order to determine the list of high-technology activities and products we start from the methodological studies carried out by the OECD on this subject, together with their adaptations to the European situation carried out by Eurostat (Instituto Nacional de Estadística, INE, 2005).

\section{High and medium-high technology}

The Spanish National Institute of Statistics INE (2013) considers technology to be the stock of knowledge that is necessary to produce new products and processes. High technology is particularly characterised by: i) fast renovation of knowledge far superior to that of other technologies, and ii) its degree of complexity, which requires a continuous research effort and a solid technological base (INE, 2005, 2011).

For statistical purposes, the definitions of high technology and medium-high technology are generally achieved by an exhaustive listing of the branches of activity (sector approach) and of the products (product approach) which are considered at a given moment to be of high technological content. It should be stressed that on establishing definitions for high and medium-high technology a certain ambiguity can be observed because the choice of thresholds for separating the segments is arbitrary (INE, 2005). On the other hand, according to Hatzichronoglou (1997) the construction of a complete classification of industries based on their technological intensity raises a series of difficulties:

- The first is the difficulty in establishing the criteria to identify the technological content of an industry, given the dynamic of change present in technologies.

- The second, the difficulty in establishing the concept of what a high technology industry is: is it one producing technology or one using technology in an intensive manner?

- A third aspect or problem is that there is always some degree of arbitrariness in the selecting of the cut-off points among the classes of technology.

It should be pointed out that owing to the very nature of high technology its definition changes over time; the high technology of the present will be traditional technology in the future if it still survives. The speed at which technological change occurs constitutes a difficulty in the measuring of this phenomenon as the field of study may vary from one moment to the next (INE, 2005).

Eurostat (2007) stresses that the subsectors of high technology and medium-high technology manufacturing are of great importance to science and technology. In accordance with this, in recent years the INE has been carrying out joint analyses for high and medium-high technology sectors, joining them both and associating statistical data in a combined manner (INE, 2011, 2013b, 2016). It is for this reason that this study also takes high and medium-high technology as

1) Universidad Pontificia Bolivariana Seccional Bucaramanga. Km 7 vía Piedecuesta, Bucaramanga. Colombia.

(2) Universidad de Cantabria. Fac. Ciencias Económicas y Empresariales. Av. Los Castros, s/n. 39005 Santander. España.

*Corresponding author: angel.cobo@unican.es 
the only industrial segment to be analysed. Moreover, previous studies (Delgado-Verde, et. al., 2011; Grimpe \& Sofka, 2009; Robertson, et. al., 2009; Santamaría, et. al., 2009; and Santos \& Vázquez, 1997) emphasise the links and special features of each of the sectors and between them.

\section{Origin of the CNAE classification in Spain}

By means of RD 475/2007 the Spanish Ministry of Economy and Finance (2007) approves the National Classification of Economic Activities (Clasificación Nacional de Actividades Económicas 2009, CNAE-2009) with the aim of reflecting the structural changes in the economy and in particular technological development. This decree is developed as from the latest revision of the latter (RD 1560/1992), which established a classification of economic activities known as CNAE-93 that underwent a minor updating in 2003. In accordance with the CNAE-2009 classification, the high and medium-high technology manufacturing industry will be made up of the sectors in Table 1 depending on the intensity of their R\&D.

Table 1. Classification of manufacturing industries in high and medium-high categories.

\begin{tabular}{ll}
\hline CNAE 2009 & Sectors \\
\hline \multirow{2}{*}{21} & High technology manufacturing sectors \\
\cline { 2 - 2 } 26 & $\begin{array}{l}\text { Manufacturing of pharmaceutical products } \\
\text { Manufacturing of computer, electronic, and optical } \\
\text { products } \\
\text { Aeronautic and spatial construction and its machinery }\end{array}$ \\
\hline & Medium-high technology manufacturing sectors \\
\cline { 2 - 2 } 20 & Chemical industry \\
25.4 & Manufacturing of arms and ammunition \\
& $\begin{array}{l}\text { Manufacturing of electrical material and equipment; } \\
\text { manufacturing of machinery and equipment n.c.o.p } \\
\text { (not classified in other places); manufacturing of motor } \\
\text { vehicles, trailers, and semi-trailers } \\
\text { Manufacturing of other transport material except: naval } \\
\text { construction; aeronautical and spatial construction and } \\
\text { its machinery } \\
\text { Manufacturing of medical and dental instruments and } \\
\text { 30-30.1 30.3 }\end{array}$ \\
\hline
\end{tabular}

Source: INE (2016)

\section{Indicators for high and medium-high technology}

With the objective of being able to analyse and measure the impact of R\&D on the various industrial sectors, a set of indicators is necessary with a clear definition that allows the carrying out of comparative analyses. High technology indicators are conceived precisely as a means of measuring the results and the impact of R\&D (INE, 2011). In this sense the OECD has been gathering data regularly from the member countries since 1960. During the 1990s it also gathered R\&D data for a selection of the economies of non member countries.

In accordance with the INE (2005) there are many sources of Spanish statistics including sets of R\&D indicators for the high and medium-high technology sector. These are as follows: i) Statistics on $\mathrm{R} \& \mathrm{D}$ activities (the proportion of companies carrying out $\mathrm{R} \& \mathrm{D}$ internally, personnel employed in R\&D activities, researchers, technicians, assistants, money spent on internal R\&D activities, and R\&D intensity...). ii) Surveys on technological innovation in companies (innovation in products, processes, innovative activities, money spent on innovative activities, on internal and external $R \& D$, on purchasing machinery and equipment related to technologically new or improved products and processes, on purchasing immaterial technology, on training related to technologically new or improved products and processes, on marketing technologically new or improved products,...) iii) industrial survey of companies (business turnover, sale of products, and added value).

However, given the existence of indicators for technological activity involving R\&D, other aspects that may play an important part are: a) technology incorporated in patents, licenses, and know-how; b) technical cooperation strategies among companies; c) rapid obsolescence of the knowledge available; d) rapid rotation of equipment (Hatzichronoglou, 1997); e) external sources such as the use of consultants, the contracting of personnel, and collaboration and external R\&D agreements (Santamaría et al., 2009) and f) The adopting of knowledge (OCED/Eurostat, 2007).

According to Hatzichronoglou (1997), the INE (2005), the OCED/ Eurostat (2007) and Santamaría et al. (2009), a set of variables linked to R\&D and innovation activities has been identified and are commonly used to establish high and medium-high indicators with an approach of classification by industrial sectors. The variables selected establish the carrying out or otherwise of various types of activities that are grouped in 5 factors and which will be described in detail in a next section.

\section{State of the high and medium-high technology manufac- turing sector in Spain}

With the objective of having an initial idea of the situation of the sector of high and medium-high technology manufacturing companies in Spain, official statistics of the Spanish National Institute of Statistics (INE) were used. The year selected for the study, 2014, corresponds to a period with very special characteristics in Spain with an economic crisis that was at its peak. According to the INE (2016), i) The business turnover of manufacturing companies in Spain from the high and medium-high technology sector was 158,058 million euros in 2014, which represented an increase of 5.2\% compared to 2013. ii) The high technology sectors employed $1,205,500$ people in 2014, which was $7.0 \%$ of the total number of the working population of the Spanish economy. $28.9 \%$ of the total number of people working in these sectors were women. The number of those working in the high technology manufacturing sectors rose to 136,400 , while those of medium-high technology employed 542,900 people. iii) Companies from high technology sectors invested 4,506 million euros in R\&D in $2014,1.5 \%$ less than the previous year. This figure meant $66.4 \%$ of the total expenses of the business sector in $\mathrm{R}+\mathrm{D}$ activities. The number of full-time employees devoted to R\&D tasks in the high technology 
sector rose to $56,165.7$, which was $0.1 \%$ less than the previous year. The branches of the high technology sector brought together $64.1 \%$ of the total number of personnel devoted to R\&D in the business sector and $66.6 \%$ of researchers. iv) $41.9 \%$ of the companies belonging to the high and medium-high technology sectors were innovative during 2012-2014. In this sense we can emphasise the branches of the manufacturing of pharmaceutical products (with $64.4 \%$ of innovative companies during the period), the manufacture of computer, electronic, and optical products (with 54.6\%) and the chemical industry (with 50.5\%).

\section{Methodology}

\section{Descriptive exploratory analysis}

The methodology used in this study is of the descriptive-exploratory type. Exploratory studies are carried out when the objective is to examine a subject that has been little studied or not approached before. Exploratory studies allow one to become familiar with relatively unknown phenomena, to obtain information on the possibility of carrying out more complete research regarding a specific context, to research new problems, to identify promising concepts or variables, to establish priorities for future research, and to suggest affirmations and assumptions (Hernández, et al. 2006). On the other hand, descriptive studies describe phenomena, situations, contexts and events and give details on what they are like and how they appear. Descriptive studies aim to specify the properties, characteristics, and profiles of people, groups, communities, processes, objects, and any other phenomena subjected to an analysis. In other words, they measure, assess, and gather data on various concepts, aspects, dimensions, or components of the phenomenon to research; their objective is not to indicate how the variables measured interact. Exploratory studies are essentially for discovering and prefiguring; descriptive studies are useful for showing precisely the dimensions of a phenomenon, event, community, context, or situation (Hernández, Fernández, and Baptista, 2006).

\section{Source and identification of the data to use}

The source of data for carrying out this study was the Survey of Business Strategies (Encuesta Sobre Estrategias Empresariales, ESEE) of 2012 of the SEPI foundation (Sociedad Estatal de Participación Industrial). In the first place a total of 44 nominal (dichotomic) and ordinal variables were selected to allow the identification the performance or nonperformance of several R\&D and innovation activities in companies of the high and medium-high technology industrial sector and other companies in industrial manufacturing sectors.

The sample consists of a total of 1540 companies of which 439 belong to high and medium-high technology segments compared with 1101 companies from other industrial manufacturing sectors. Within companies of technological segments the sample includes representatives of the chemical and pharmaceutical industry (137 companies), computer and electronic products (31 companies), machinery and electrical material (74 companies), agricultural and industrial machines (110 companies) and motor vehicles (87 companies).
The sample also includes companies of different sizes. If we use a classification between companies with 200 workers or less and companies with over 200 workers, the group of smaller companies is more numerous in both industrial sectors. In high and mediumhigh technology companies those with 200 workers or less represent $69.25 \%$ of the sample compared with $84.74 \%$ in the remaining companies. In other words, the group of companies with over 200 workers has a higher proportion with $30.75 \%$ in the high technology sector in comparison with $15.26 \%$ in the segment of other manufacturing sectors.

\section{State of the high and medium-high technology industrial manufacturing sector in Spain}

As has been mentioned, in order to identify relevant characteristics that allow the description of the R\&D and innovation activities in high and medium-technology companies a set of 44 nominal dichotomic variables (existence or not) were considered. According to the type of activity they measure, the variables were divided into the following 5 factors:

1) Marketing activities

2) Technological activities

3) Activities of incentives and financing in $R \& D$ and innovation

4) Activities of innovation

5) Personnel contracted devoted to R\&D activities

The following sections will indicate the variables corresponding to each factor and at the same time they will present the results of the analysis of their values in the companies of the sample. Particular attention will be paid to the most significant differences when the results of the subgroup of the 439 high and medium-high technology companies are compared with those of the 1101 manufacturing companies from other sectors.

\section{Marketing activities}

The variables related to marketing activities include 7 that measure whether products not manufactured by the company are marketed and whether import and export activities or internet sales are carried out and the impact of the latter on business results. Table 2 includes an identifier of the variable together with its name, a brief description, and the percentages of companies in the two subgroups of the sample (high and medium-high technology on the one hand and the remainder on the other) carrying out the corresponding activity. The last column in the table shows the ratio between the number of high and medium-high technology companies and companies from other manufacturing sectors carrying out the activity. 
Table 2. Marketing activities: percentage comparison by activity type and by industrial manufacturing sector.

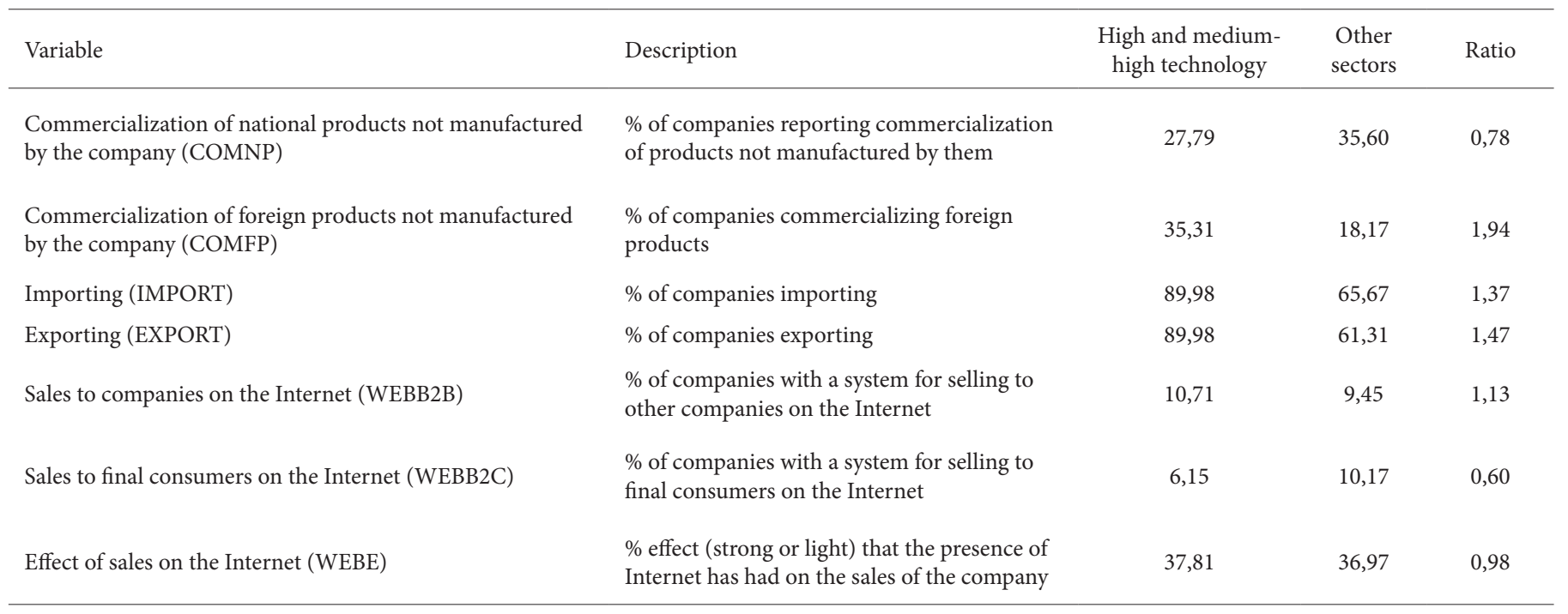

As can be seen in both Table 2 and Figure 1, both in the high and medium-high technology industrial manufacturing sector and in other sectors the percentage of companies commercializing products that they have not manufactured is greater in the case of products manufactured in other countries than in Spain. Moreover, this type of marketing activities is more frequent in high and medium-high technology companies.

It should also be stressed that $89.98 \%$ of high and medium-high technology companies are involved in importing and $89.98 \%$ in exporting. In the same way, all these activities are more numerous in the high and medium-high segment in relation to other manufacturing sectors in ratios of 1.37:1 for importing and 1.47:1 for exporting respectively.

Regarding e-business activities, the percentage of companies making sales on the Internet to other companies (B2B models) is $9.45 \%$ for companies belonging to the segment of other industrial manufacturing sectors and $10.71 \%$ for companies in the high and medium-high technology segment, which are very similar figures. However, in ebusiness sales to final consumers (B2C models) high technological companies have less activity. This is confirmed on analysing the variable in which companies declare the effect that e-business has on their trading; $36.97 \%$ of manufacturing companies from other sectors declare a strong or light effect while in the sector of higher technology this percentage is $37.81 \%$.

It can be observed, particularly in Figure 1, how the profiles of the activities of companies from the high and medium-high technology industrial segment and from that of the remaining manufacturing companies follow a similar pattern in which the intensity of the activities is greater in the high and medium-high technology company segment.
Figure 1. Marketing activities: percentage comparison by activity type and by industrial manufacturing sector.

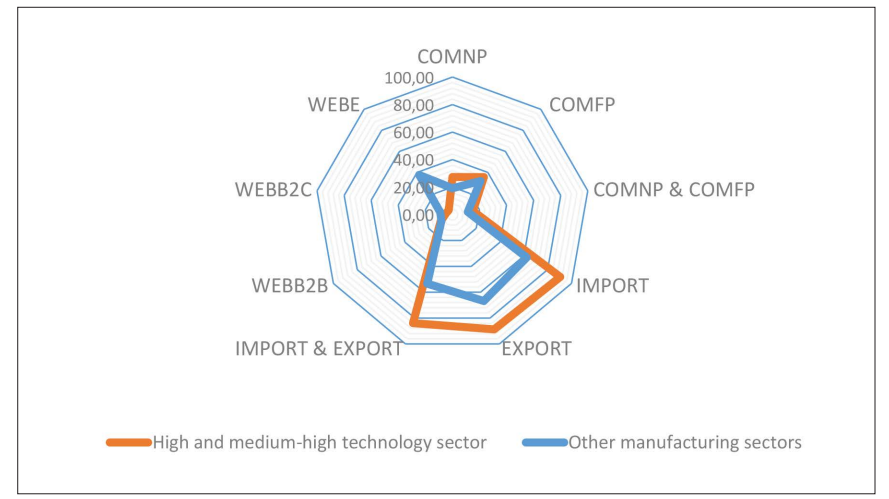

\section{Technological activities}

The second of the factors to analyse is determined by a total of 16 variables that refer to aspects such as the existence of technological cooperation agreements, the acquiring of capital goods to improve products, R\&D activities, the existence of technology management or committees, a plan of innovation activities, subcontracting products or components, using advisers to find out about technology, indicators of results of innovation, the assessment of perspectives of technological change, technological collaboration with clients, competitors, suppliers, and with universities, participation in EU research programmes, and the registering of patents both in Spain and abroad. Together with the values measured in the sample, all these variables are included in Table 3. Figure 2 aims to illustrate the differences observed on analysing these variables in the high and medium-high technology industrial segments and other manufacturing sectors. The values shown indicate the percentages of companies from each segment carrying out the corresponding technological activity. 
Table 3. Technological activities: percentage comparison by activity type and by industrial manufacturing sector.

\begin{tabular}{|c|c|c|c|c|}
\hline Variable & Description & $\begin{array}{l}\text { High and medium- } \\
\text { high technology }\end{array}$ & $\begin{array}{l}\text { Other } \\
\text { sectors }\end{array}$ & Ratio \\
\hline Technological Cooperation Agreements (TCA) & $\%$ of companies with cooperation agreements (joint venture) & 5,92 & 2,45 & 2,42 \\
\hline $\begin{array}{l}\text { Acquiring Capital Goods to Improve Products } \\
\text { (ACG) }\end{array}$ & $\%$ of companies acquiring capital goods for improving products & 22,10 & 14,71 & 1,50 \\
\hline R\&D Activities (RDA) & $\%$ of companies with $\mathrm{R} \& \mathrm{D}$ activities contracted or carried out & 61,50 & 27,70 & 2,22 \\
\hline Technology Management or Committee (TMC) & $\%$ of companies with technology management or committees & 45,10 & 15,53 & 2,90 \\
\hline $\begin{array}{l}\text { Using advisers to find out about technology } \\
\text { (UAT) }\end{array}$ & $\%$ of companies using advisers to find out about technology & 27,79 & 17,08 & 1,63 \\
\hline Innovation result indicators (IRI) & $\%$ of companies drawing up innovation result indicators & 31,66 & 14,08 & 2,25 \\
\hline $\begin{array}{l}\text { Assessment of perspectives of technological } \\
\text { change (APTC) }\end{array}$ & $\%$ of companies assessing perspectives of technological change & 37,59 & 19,16 & 1,96 \\
\hline $\begin{array}{l}\text { Collaboration with universities and/or } \\
\text { technological centres (CUTC) }\end{array}$ & $\begin{array}{l}\% \text { of companies with technological collaboration with } \\
\text { universities and/or technological centres }\end{array}$ & 40,32 & 18,71 & 2,15 \\
\hline Participation in EU research programmes (PIUE) & $\%$ of companies participating in European Union programmes & 1,82 & 0,91 & 2,01 \\
\hline Patents registered abroad (PATEXT) & $\begin{array}{l}\% \text { of companies that during the accounting period register } \\
\text { patents outside Spain }\end{array}$ & 6,83 & 1,63 & 4,18 \\
\hline Patents registered in Spain (PATESP) & $\begin{array}{l}\% \text { of companies that during the accounting period register } \\
\text { patents in Spain }\end{array}$ & 7,74 & 2,63 & 2,94 \\
\hline
\end{tabular}

Figure 2. Technological activities: percentage comparison by activity type and by industrial manufacturing sector.

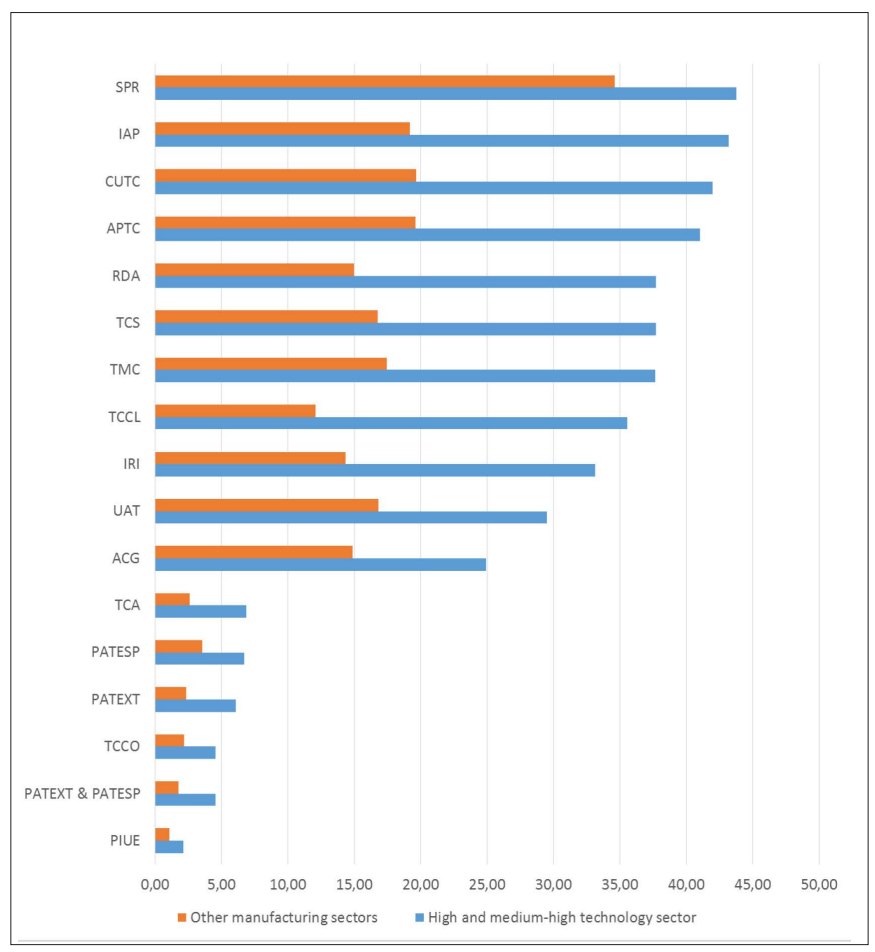

In Figure 2 four subgroups of technological activities in high and medium-high technology companies can be observed; they are classified according to the degree of appearance in the sample analysed:

- The first subgroup includes those activities carried out by over $40 \%$ of companies in the high and medium-high technology segment. It is here that we can find activities such as the subcontracting of products or components, the drawing up of innovation activity plans, technological collaboration with universities and/or technological centres, the existence of technological management or committees and the contracting of R\&D.

- The second sub-group, with percentages of activities carried out of between 30 and 38\%, includes activities such as, technological collaboration with clients and suppliers, the assessment of perspectives of technological change and the drawing up of innovation result indicators.

- The third subgroup, which includes between 20 and $30 \%$ of the companies in the segment, includes activities such as the use of advisers to find out about technology, and the acquiring of capital goods for improving products.

- Finally there is a subgroup of activities present in small percentages of companies (less than 8\%): technological cooperation agreements, registering patents in Spain or elsewhere, technological collaboration agreements with competitors, and participation in European Union research programmes. 
In the case of manufacturing companies from other industrial sectors, the most common activities are the subcontracting of products or components, the contracting of $\mathrm{R} \& \mathrm{D}$, the assessment of perspectives of technological changes, the technological collaboration with universities, but all of these with a lower range of intensity (in between 18 and $22 \%$ of companies) in comparison to companies belonging to the high and medium-high technology segment. Precisely when the results obtained in the segment of technology companies are compared with those of the remainder of companies, a similar pattern can be observed in relation to the activities carried out (see Figure 3). Nevertheless, in general terms for each company from other sectors carrying out one of the activities there are on average 2.22 technological companies carrying out this activity. The most striking differences are found in technical cooperation with clients (for each company from other sectors carrying this out there are more than 3 technological companies) and in the registering of patents both in Spain and elsewhere.

Figure 3. Technological activities: percentage comparison by activity type and by industrial manufacturing sector.

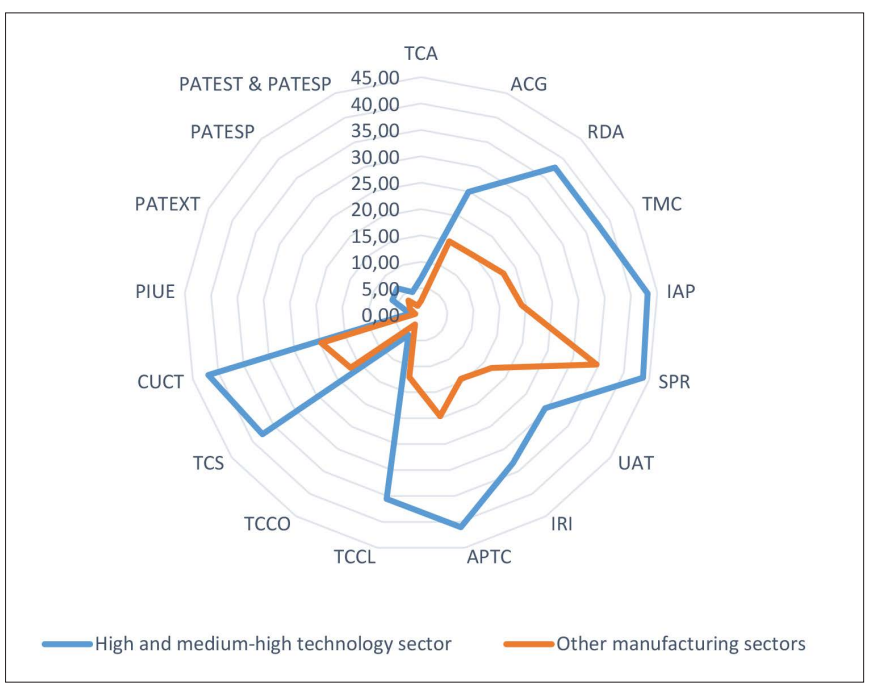

Activities of incentives and financing in R\&D and innovation

Within the factor of incentives and financing in $R \& D$ and innovation only two variables have been considered, on the one hand identifying whether companies apply tax incentives for R\&D and technological innovation, and on the other whether they choose to finance innovation with subsidised loans. Table 4 shows the percentages of companies in the two industrial segments in which these variables have a positive reading. As can be seen, both activities are more frequent in companies from the high and medium-high technology industrial segment in a ratio of almost 3 if we compare them to other sectors in the case of incentives for $\mathrm{R} \& \mathrm{D}$, and more than double in the case of the use of subsidised loans.
Table 4. Activities of incentives and financing in R\&D and innovation: percentage comparison by activity type and by industrial manufacturing sector.

\begin{tabular}{|c|c|c|c|c|}
\hline Variable & Description & $\begin{array}{l}\text { High and } \\
\text { medium- } \\
\text { high } \\
\text { technology }\end{array}$ & $\begin{array}{l}\text { Other } \\
\text { sectors }\end{array}$ & Ratio \\
\hline
\end{tabular}

$\begin{array}{lllll}\text { Applying } & \text { \% of companies } & & & \\ \text { R\&D tax } & \text { applying R\&D tax } & 32,35 & 11,44 & 2,83 \\ \text { incentives } & \text { incentives } & & & \\ \text { (RDIN) } & & & & \end{array}$

$\begin{array}{lllll}\begin{array}{l}\text { Financing } \\ \text { innovation }\end{array} & \begin{array}{l}\text { \% of companies } \\ \text { financing }\end{array} & 20,05 & 7,27 & 2,76 \\ \text { with } & \text { innovation with } & & & \\ \text { subsidised } & \text { subsidised loans } & & & \\ \text { loans (FISL) } & & & \end{array}$

\section{Innovation activities}

Innovation activities can be divided into four categories: innovations in marketing, in organisational methods, in products, and in processes. In total the 16 variables included in Table 5 have been considered. The first category contains innovations in marketing by design, by promotion, in sales channels, and in pricing. Innovations in organisational methods also include innovations in work organisation or in external relations. When analysing innovations in products a differentiation is made between innovations in new components, new functions, and new materials. Finally, process innovations may be due to the use of new equipment, new computer programmes, or new techniques. Table 5 includes the percentages of companies considered in the two segments carrying out the various activities of innovation. As in the previous cases, a greater intensity in innovation actions can be observed in the high and medium-high technology segment of companies. 
Table 5. Innovation activities.

\begin{tabular}{|c|c|c|c|c|}
\hline Variable & Description & $\begin{array}{c}\text { High and } \\
\text { medium-high } \\
\text { technology }\end{array}$ & $\begin{array}{l}\text { Other } \\
\text { sectors }\end{array}$ & Ratio \\
\hline Marketing innovations (MKI) & $\%$ of companies carrying out marketing innovations & 22,55 & 19,53 & 1,15 \\
\hline Innovations in retail channels (IRCH) & $\begin{array}{l}\% \text { of companies carrying out innovations in retail } \\
\text { channels }\end{array}$ & 7,29 & 8,08 & 0,90 \\
\hline Innovations in marketing by design (IDES) & $\begin{array}{l}\% \text { of companies carrying out innovations in marketing by } \\
\text { design }\end{array}$ & 12,76 & 11,35 & 1,12 \\
\hline Innovations in marketing by promotion (IPROM) & $\begin{array}{l}\% \text { of companies carrying out innovations in marketing by } \\
\text { promotion }\end{array}$ & 11,16 & 9,81 & 1,14 \\
\hline Innovations in organisational methods (IOM) & $\begin{array}{l}\% \text { of companies carrying out innovations in organisational } \\
\text { methods }\end{array}$ & 31,21 & 18,98 & 1,64 \\
\hline $\begin{array}{l}\text { Innovations in the management of external } \\
\text { relations (IMER) }\end{array}$ & $\begin{array}{l}\% \text { of companies carrying out innovations in the } \\
\text { management of external relations }\end{array}$ & 14,35 & 9,54 & 1,50 \\
\hline Product innovation by new functions (IPNF) & $\%$ of product innovation by new functions & 23,01 & 9,08 & 2,53 \\
\hline Product innovation by new materials (IPNM) & $\%$ of product innovation by new materials & 20,05 & 9,99 & 2,01 \\
\hline Obtaining process innovations (IPR) & $\%$ of process innovations & 43,28 & 28,52 & 1,52 \\
\hline Process innovations by new equipment (IPRNE) & $\%$ of process innovations by new equipment & 33,03 & 21,71 & 1,52 \\
\hline $\begin{array}{l}\text { Process innovations by computer programs } \\
\text { (IPRCP) }\end{array}$ & $\%$ of process innovations by computer programs & 20,96 & 10,90 & 1,92 \\
\hline Process innovations by new techniques (IPRNT) & $\%$ of process innovations by new techniques & 28,25 & 14,17 & 1,99 \\
\hline
\end{tabular}

In Figure 4 it can be observed that those innovation activities that are most frequent in high and medium-high technology companies, being present in over $30 \%$ of companies, are process innovations, innovations by new equipment, innovations in organisational methods, and product innovations. At a second level, with percentages of between 20 and $30 \%$, we find innovation in work organization, process innovations by the use of new techniques, product innovations by new functions or new components, marketing innovations, process innovations by the use of computer programmes and product innovations by new materials. With a presence in less than $15 \%$ of companies we find innovations in the management of external relations, in marketing by design or by promotion, in marketing outlets, and in pricing innovations.

Figure 4. Innovation activities.

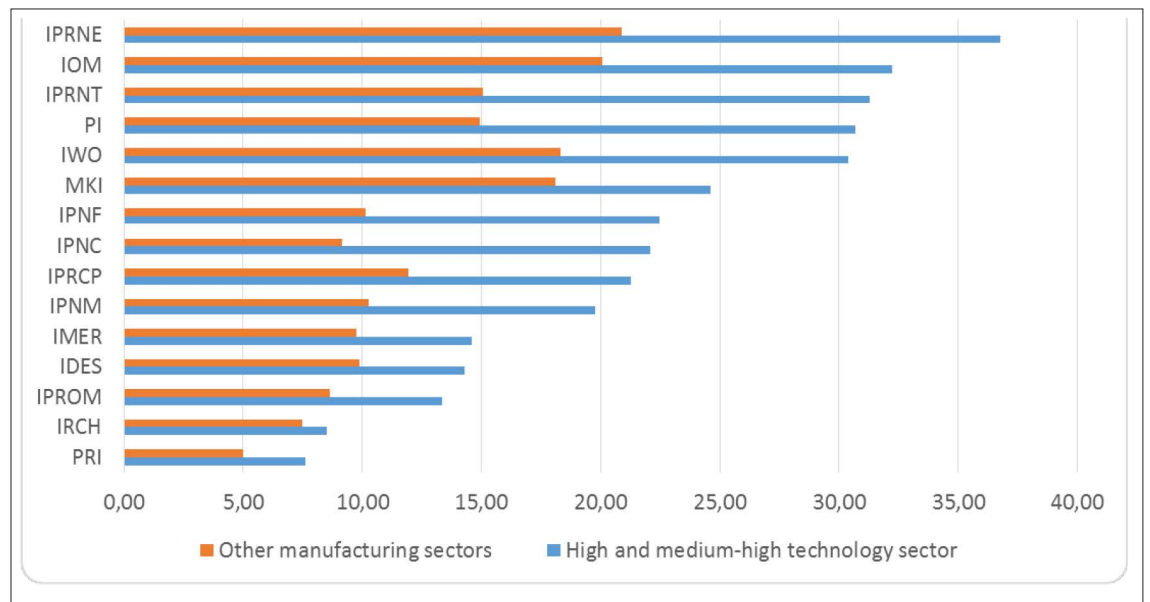

Figure 5 shows in overall graphic form that both high and mediumhigh technology companies and companies from other industrial sectors follow a similar pattern in relation to the activities carried out. However, in general terms innovation activities are more frequent in technological companies; for each company from other industrial sectors there are on average 1.69 companies from the high and medium-high technology industrial segment carrying out such activities. 
Figure 5. Innovation activities.

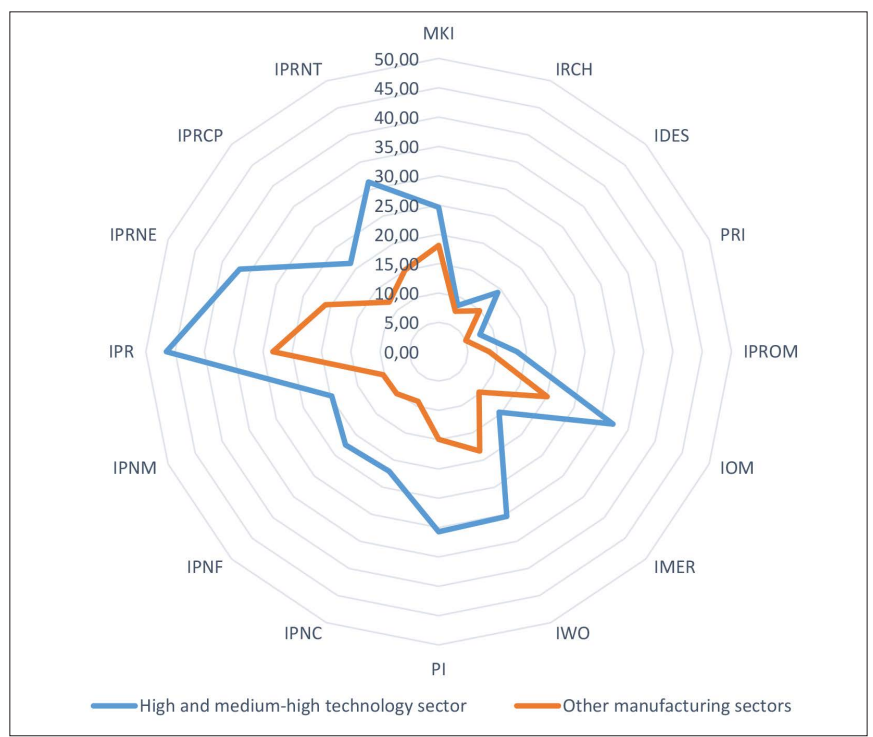

\section{Personnel contracted devoted to R\&D activities}

Finally, the last factor that was considered important in the analysis was that of the human resources that companies devote to R\&D activities. In this case only 3 variables are considered: if during the year the companies recruited personnel with R\&D business experience, personnel with professional experience in the R\&D public system, or engineers and/or recent graduates. Table 6 shows the percentages of the companies of the two segments in which variables are positive; this same information is shown in graphic form in Figure 6.

Table 6. Personnel contracted devoted to R\&D activities

\begin{tabular}{|c|c|c|c|c|}
\hline Variable & Description & $\begin{array}{c}\text { High and } \\
\text { medium-high } \\
\text { technology }\end{array}$ & $\begin{array}{l}\text { Other } \\
\text { sectors }\end{array}$ & Ratio \\
\hline $\begin{array}{l}\text { Recruiting } \\
\text { personnel with } \\
\text { R\&D business } \\
\text { experience } \\
\text { (RPBE) }\end{array}$ & $\begin{array}{l}\% \text { of } \\
\text { companies } \\
\text { recruiting } \\
\text { people with } \\
\text { R\&D business } \\
\text { experience }\end{array}$ & 10,71 & 3,09 & 3,47 \\
\hline $\begin{array}{l}\text { Recruiting } \\
\text { people with R\&D } \\
\text { professional } \\
\text { experience in } \\
\text { the public sector } \\
\text { (RPPS) }\end{array}$ & $\begin{array}{l}\% \text { of } \\
\text { companies } \\
\text { recruiting } \\
\text { people } \\
\text { with R\&D } \\
\text { experience } \\
\text { in the public } \\
\text { sector }\end{array}$ & 4,10 & 0,82 & 5,02 \\
\hline $\begin{array}{l}\text { Hiring of } \\
\text { engineers and/or } \\
\text { recent graduates } \\
\text { (GRAD) }\end{array}$ & $\begin{array}{l}\% \text { of } \\
\text { companies } \\
\text { hiring } \\
\text { engineers } \\
\text { and/or recent } \\
\text { graduates }\end{array}$ & 32,57 & 10,17 & 3,20 \\
\hline
\end{tabular}

Figure 6. Personnel contracted devoted to R\&D activities

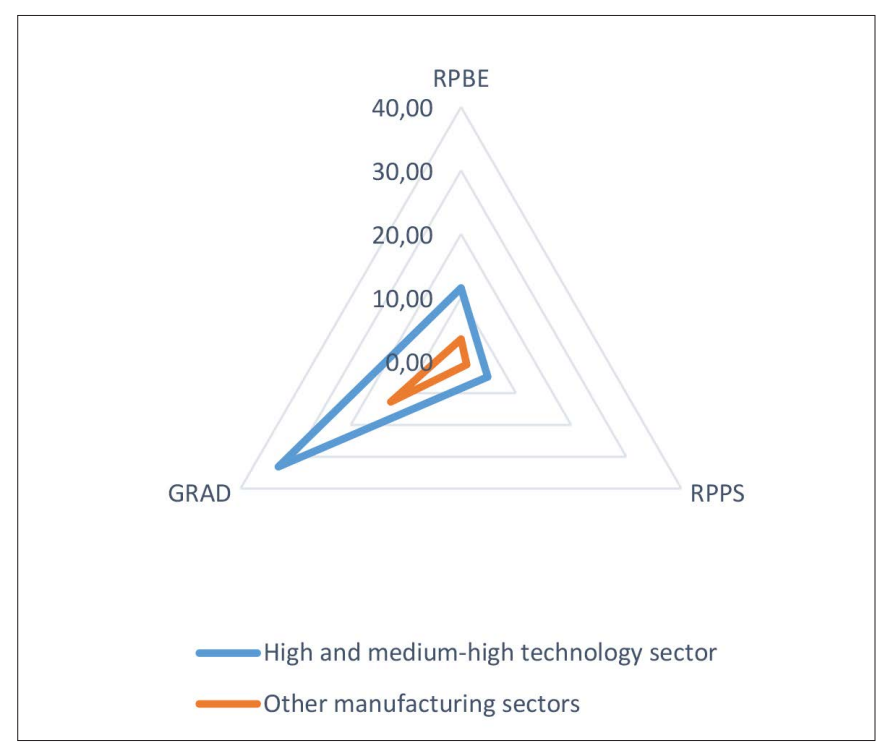

In both Table 6 and in the corresponding Figure 6 the same pattern can again be seen as to the contracting of R\&D personnel in the two business segments, but to a substantially higher degree in high and medium-high technology companies. The effort made to contract research personnel is more than trebled in these companies. The difference that can be observed in the hiring of personnel with R\&D experience in the public sector is particularly striking. It is also noticeable that a third of the companies in the technological sector contracted recent graduates, more than triple the figure for the remaining sectors.

\section{Conclusions}

In essence this exploratory and descriptive study has served to gather preliminary evidence allowing the identification of characteristics of high and medium-high technology manufacturing companies which differentiate these companies from those belonging to other industrial manufacturing industries in Spain. Considerable differences have been observed in reference to the intensity with which these companies carry out different activities related to $\mathrm{R} \& \mathrm{D}$ and innovation. It should be emphasised that the study has been carried out in consolidated form for each of the two segments established without a differentiation by industrial subsector type within each one of them. Some of the most important aspects observed in the study are highlighted below.

Small and medium-sized enterprises with 200 workers or less are predominant in all industrial sectors; however this predominance is not so great in companies in the high and medium-high technology segment. To be precise, $69.25 \%$ of the companies in this segment are small or medium-sized enterprises compared with a percentage of $84.74 \%$ in other sectors. 
It is observed that the profile of activities of companies belonging to the high and medium-high technology industrial segment and to other industrial manufacturing sectors follows a similar pattern. However, the intensity of the activities is greater in the segment of high and mediumhigh technology companies. In general terms, for each company from other industrial sectors carrying out the activities studied, 2.07 companies have this same activity in the high and medium-high technology sector. Perhaps the only aspect of those analysed in which a rather different pattern is observed is that related to e-business, in which technological companies rely more on B2B models and not so much on B2C models. Another noticeable difference is that in companies in other manufacturing sectors there is a greater proportion of companies that commercialize products not manufactured.

It has been possible to confirm that a set of technological activities exist that are quite common in high and medium-high technology companies; they are present in over $50 \%$ of the companies of the sample. These actions include importing, exporting and contracting R\&D activities. On a second level can be found the existence in the companies of technology management or committees, the subcontracting of products or components, process innovations, management based on innovation plans, collaboration with universities and research centres, effect of sales on the Internet, the assessment of perspectives of technological change, technological collaboration with suppliers and commercialization of foreign products not manufactured by the company; these activities have been declared by over $35 \%$ of technological companies. It is also of note that almost $30 \%$ of the companies in the technological segment have recourse to advisers to find out about technology. Some of these activities are also relatively common in companies from other sectors, but in clearly lower percentages.

It may be important to analyse those actions in which the percentage of their presence in technological companies is considerably greater than in other companies. The most notable differences are found in the hiring of personnel with experience in $\mathrm{R} \& \mathrm{D}$; for example, during the year some $4 \%$ of technological companies hired personnel with professional R\&D experience in the public sector compared with less than $1 \%$ in companies from other sectors. It should also be understood that the situation prevalent during the study was one of economic crisis and the need to reduce the public deficit, which led to major cutbacks in research personnel in research centres and universities. The hiring of new personnel with $\mathrm{R} \& \mathrm{D}$ business experience was also considerably higher in technological companies with a percentage that trebled that of the remaining sectors. Differences were also observed in the hiring of recent graduates, which is multiplied by 3.2 in technological companies. It therefore seems clear that an important feature of these companies is the faith placed in highly qualified human capital and experience in research, development, and innovation.

Other activities in which the percentage of technological companies that have carried them out during the year under study are significantly higher than those of other sectors are: the registering of patents in both Spain and elsewhere, the existence of technological cooperation agreements, the existence of technological management, application to R\&D tax incentives, access to subsidised loans for financing innovation and product innovations (by new functions, components, or materials). In general these companies have much more intense $\mathrm{R}+\mathrm{D}$ activity, they are concerned with innovation in its different facets and are aware of the importance of technological supervision and devote resources to it. In relation to the first aspect, that of innovation, there are 3 subgroups in high and medium-high technology companies. The first concerns the carrying out of process innovation activities by new equipment and new techniques, of organisational methods, and of product innovations; a second subgroup concerns the carrying out of marketing innovation activities, production innovations by new functions, by new components, by new materials, and process innovation by the use of computer programmes. The third subgroup is more orientated towards the carrying out of innovation activities in the administration of external relations, in marketing by design and promotion, innovation in marketing outlets, and pricing innovation.

Finally, significant differences have also been observed in the search for external sources of financing. It is observed that during the year under study a $20.05 \%$ of technological companies resorted to subsidised loans for innovation activities and $32.35 \%$ made use of R\&D tax incentives, compared with percentages of 7.27 and $11.44 \%$ respectively in the remaining sectors. There are also clear differences in participation in research programmes of the European Union, where despite the fact that only $2 \%$ of companies took part this figure doubled that of companies from the remaining sectors.

This study has achieved its aim of identifying characteristics of companies from industrial manufacturing sectors linked to high and medium-high technology and establishes a basis for possible more complex future studies. As a future line of work we propose the use of data mining techniques to explore the data of the survey analysed and discover hidden relationships in the data. Although the study has been a static one concentrating on only one year, it is true that this moment in time is an important one that can justify the study as it refers to an economic crisis. It is proposed to carry out a dynamic study in the future as complete data are obtained from the Business Strategy Survey (Encuesta Sobre Estrategias Empresariales, ESEE) of the SEPI Foundation on later periods.

\section{References}

Delgado-Verde, M., Martín-de-Castro, G., Navas-López, J. E., \& CruzGonzález, J. (2011). Capital social, capital relacional e innovación tecnológica. Una aplicación al sector manufacturero español de alta y media-alta tecnología. Cuadernos de Economía Y Dirección de La Empresa, 14(4), 207-221. http://doi.org/10.1016/j.cede.2011.04.001

Eurostat. (2007). Eurostat regional yearbook 2007. Luxemburgo: Eurostat. Retrieved from http://ec.europa.eu/eurostat/documents/3217494/5615357/KS-AF-07-001-07-EN.PDF/40b31d3e99b1-4864-bd7a-6887abab8a61 
Grimpe, C., \& Sofka, W. (2009). Search patterns and absorptive capacity: Low- and high-technology sectors in European countries. Research Policy, 38(3), 495-506. http://doi.org/10.1016/j.respol.2008.10.006

Hatzichronoglou, T. (1997). Revision of the High-Technology Sector and Product Classification (OCDE/GD(97)216 No. 1997/02). Paris. Retrieved from http://dx.doi.org/10.1787/134337307632

INE. (2005). Indicadores de ciencia y tecnología 2003. Madrid: INE. Servicio Editorial.

INE. (2011). Instituto Nacional de Estadística. Indicadores del sector de alta tecnología. Metodología General. Reporte en línea, Madrid: Instituto Nacional de Estadística INE 2011. Retrieved from http://www.ine.es/daco/daco43/notaiat.pdf

INE. (2013). Indicadores del sector de alta tecnología. Año 2011. Resultados definitivos. Notas de prensa. Retrieved from http://www.ine.es/prensa/np768.pdf

INE. (2016). Indicadores del sector de alta tecnología, Años 2014. Resultados definitivos. Retrieved February 25, 2016, from http://www.ine.es/prensa/np959.pdf

Instituto de Estudios Fiscales (IEF). (2014). La evaluación ex ante del Programa Operativo de Crecimiento Inteligente (POCInt). Retrieved from http://www.dgfc.sgpg.meh.es/sitios/dgfc/es-ES/ipr/fcp1420/p/ Prog_Op_Plurirregionales/Documents/Eval_ex_ante_POCINT.pdf

MINISTERIO DE ECONOMIA Y HACIENDA. (2007). Real Decreto 475/2007, de 13 de abril, por el que se aprueba la Clasificación Nacional de Actividades Económicas 2009 (CNAE-2009). Retrieved February 11, 2016, from https://www.boe.es/diario_boe/txt. php?id=BOE-A-2007-8824

OCDE. (2011). Science and Technology Indicators. OCDE (Vol. 2011). Retrieved from http://www.oecd.org/science/inno/49501885.pdf
OECD/Eurostat. (2007). Manual de Oslo. (GRUPO TRAGSA, Ed.) (3a Edición). Madrid: Tragsa. http://doi.org/10.1787/9789264065659-es

Robertson, P., Smith, K., \& von Tunzelmann, N. (2009). Innovation in low and medium-technology industries. Research Policy, 38(3), 441-446. http://doi.org/10.1016/j.respol.2008.10.019

Santamaría, L., Nieto, M. J., \& Barge-Gil, A. (2009). Beyond formal $\mathrm{R} \& \mathrm{D}$ : Taking advantage of other sources of innovation in low- and medium-technology industries. Research Policy, 38(3), 507-517. http://doi.org/10.1016/j.respol.2008.10.004

Santos, L., \& Vázquez, R. (1997). La innovación en las empresas de alta tecnología: Factores Condicionantes del Resultado Comercial. Oviedo: Universidad de Oviedo. Facultad de Ciencias Económicas y Empresariales.

\section{Biographical notes about authors:}

Marco Villamizar: Professor of the School of Industrial Engineering at the Universidad Pontificia Bolivariana, Seccional Bucaramanga (Colombia). Research areas of interest: Management and technology. Msc in Business and Technology. Member of the research group in Business, Education and ICT - GeeTIC.

Angel Cobo: Professor in the Department of Applied Mathematics and Computational Sciences at the University of Cantabria (Spain). $\mathrm{PhD}$ in Applied Mathematics He specializes in the mathematical modelization for the solution of scientific and engineering problems, using and developing new techniques in operations research, decision theory, and metaheuristics.

Rocio Rocha: Professor in the Department of Business Administration at the University of Cantabria (Spain). $\mathrm{PhD}$ in Business Administration. Research areas of interest: data mining, business intelligence, information systems and new model of business based on information and communication technologies. 